\title{
Fertilisers mediate the short-term effects of sheep grazing in the Icelandic highlands
}

\author{
Tara A Mulloy ${ }^{1,2 *}$, Isabel C Barrio ${ }^{2}$, Katrín BJörnsdóttir ${ }^{2}$, Ingibjörg Svala \\ JóNSDÓTTIR ${ }^{3}$, AND DAVID S HIK ${ }^{1}$ \\ ${ }^{\prime}$ Department of Biological Sciences, Simon Fraser University, 8888 University Drive, Burnaby, British Columbia, Canada \\ ${ }^{2}$ Agricultural University of Iceland, Árleyni 22 Keldnaholt 112 Reykjavik, Iceland \\ ${ }^{3}$ Institute of Life and Environmental Sciences, University of Iceland, Sturlugata 7101 Reykjavik, Iceland \\ Email: tmulloy@sfu.ca*,isabel@lbhi.is,katbjo@gmail.com,isj@hi.is,dhik@sfu.ca \\ *corresponding author
}

\begin{abstract}
Sustainable grazing management in tundra ecosystems is receiving increasing attention. In the Icelandic highlands, past grazing practices have played a major role in the extensive soil erosion, leaving many parts of this tundra rangeland in poor condition. However, the impacts of current grazing practices are not well understood. We measured the short-term effect of grazing by comparing the amount of bare ground and aboveground biomass in grazed and ungrazed plots, with and without fertiliser application, in adjacent dwarfshrub heaths and sparsely vegetated areas, at two sites within and outside the volcanic active zone. Grazing did not affect the amount of bare ground, but in the fertilised plots grazing consistently reduced plant biomass (mainly graminoids). Fertiliser application can increase grazing intensity, which can counteract the additional biomass accumulation. Consequently, the removal of biomass by sheep needs to be considered when fertilisers are used as part of a strategy to combat erosion.
\end{abstract}

Keywords: fertiliser application, soil erosion, sheep grazing, subarctic rangelands.

\section{YFIRLIT \\ Áburður jafnar skammtímaáhrif sauðfjárbeitar á hálendi Íslands.}

Á síðustu árum hefur verið lögð aukin áhersla á sjálfbæra beitarstjórnun á norðlægum slóðum. Pung sauðfjárbeit fyrri tíma á Íslandi átti ríkan pátt í hnignun lands og jarðvegseyðingu, sem leiddi til slæms ástands víða á aftéttum hálendisins. Áhrif núverandi beitarstjórnunar eru hins vegar ekki vel pekkt. Í pessari rannsókn mældum við áhrif sauðfjárbeitar á pekju ógróins yfirborðs og lífmassa gróðurs, með pví að bera saman beitta og óbeitta reiti, með og án áburðar, í tveimur mismunandi búsvæðum (fjalldrapamóa og mel) á tveimur svæðum, innan og utan eldgosabeltisins. Sauðfjárbeit hafði ekki áhrif á pekju ógróins yfirborðs, en í ábornu reitum minnkaði beitin lífmassa plantna (aðallega grasa). Beitarálag getur aukist verulega á ábornum svæðum og vinnur pað gegn uppsöfnun lífmassa. Við notkun áburðar til að stemma stigu við jarðvegseyðingu á afréttum parf pví að taka tillit til pess lífmassa sem fjarlægður er með aukinni beit.

\section{INTRODUCTION}

Extensive sheep grazing on land that otherwise has little agricultural value is an important practice in many Nordic regions (Ross et al.
2016). The use of these areas for grazing is generally cost-effective, since producing free range animals requires minimal maintenance 
(Gudmundsson \& Thórhallsdóttir 1999). However, Nordic rangelands are especially sensitive to disturbances such as overgrazing because they experience cold temperatures and short growing seasons that make vegetation slow to reestablish (Forbes et al. 2001, Ross et al. 2016). As a consequence, the sustainability of sheep grazing practices in these areas remains controversial (Ross et al. 2016).

The Icelandic highlands are located in the interior of the country and, as typical for the region, they experience regular volcanic activity, glacial flooding and aeolian deposition (Thórhallsdóttir 1997). These areas are also used as communal rangelands, traditionally during summer for sheep grazing (Arnalds et al. 1987). Vegetated areas in the highlands consist mostly of dwarf-shrub heathlands dominated by shrubs and other vascular plants and occasional wetlands, as well as scattered volcanic deserts supporting a few graminoid or forb species (Thórhallsdóttir 1997). Once the vegetation cover is disturbed, the easily eroded volcanic soils are rapidly blown or washed away. The combination of natural disturbances and grazing in the highlands have resulted in extensive soil erosion and degradation (Arnalds 2015). This degradation is likely more pronounced within the volcanic active zone of Iceland, where soils are geologically younger and less welldeveloped (Arnalds 2015).

Although livestock grazing has been identified as one of the potential drivers of rangeland degradation in the highlands (Arnalds \& Barkarson 2003), the ecological impacts of sheep grazing in these areas are not well resolved (Marteinsdóttir et al. 2017). Sheep grazing tends to increase the amount of exposed bare ground and reduce the cover of vascular plants, both within and outside the volcanic active zone (Marteinsdóttir et al. 2017). However, the impacts of grazing likely vary with habitat characteristics (Gough et al. 2012) and soil conditions (Stark et al. 2002, Eskelinen 2008).

Efforts to restore eroded land in Iceland have often included fertiliser application (Gunnlaugsdóttir 1985, Arnalds et al. 1987, Greipsson \& El-Mayas 1999), sometimes in combination with seeding agronomic grasses (Grétarsdóttir et al. 2004). Fertiliser application can increase productivity of tundra plants (Gough et al. 2007, Morrissette-Boileau et al. 2018), accelerate succession (Chapin 1980, Shaver \& Chapin 1995, Óskarsson et al. 2006, Gough et al. 2016), and reduce the amount of exposed bare ground (Arnalds et al. 1987). Fertiliser applications can also reduce species diversity (Harpole et al. 2017), by increasing the dominance of more palatable plant species (Gough et al. 2012). These increases in productivity and palatability can create patches that attract further grazing (Ball et al. 2000, Grellmann 2002), counteracting the effectiveness of fertilisers as a restoration tool.

In this study we assessed how the application of fertilisers may influence the short-term effects of sheep grazing across habitats that vary in vegetation cover and in areas that differ in soil characteristics. To measure the effect of grazing we compared pairs of fenced and unfenced plots in dwarf-shrub heath and sparsely vegetated areas at two locations, inside and outside the volcanic active zone, with and without fertilisers. We measured (1) exposed bare ground cover as a proxy for soil erosion, (2) total aboveground plant biomass and (3) the abundance of specific plant functional groups.

Based on previous knowledge on the impacts of sheep grazing in Iceland, we predicted that the effect of grazing would increase the percent cover of bare ground and reduce aboveground plant biomass. We also predicted that increases in the cover of bare ground as a result of grazing would be stronger within the volcanic active zone where soils are more susceptible to soil erosion (Arnalds 2015). Based on the preference and selectivity of sheep (Austrheim et al. 2008, Mobæk et al. 2012), we predicted that the effect of grazing on plant biomass would be more pronounced for graminoids and forbs than other plant functional types. A greater effect of grazing on bare ground might also be more evident in the already exposed, sparsely vegetated habitats than in the well-vegetated dwarf-shrub heath. 


\section{METHODS}

Study area and experimental design

In early summer 2016, we established a field experiment to assess the effects of grazing across a range of environmental conditions in the highlands of Iceland. The highlands are dominated by subarctic-alpine tundra vegetation, experience short growing seasons and have been traditionally used for summer grazing by domestic sheep (Thórhallsdóttir 1997). One site was located inside (Peistareykir; $\left.65^{\circ} 52^{\prime} 26^{\prime \prime} \mathrm{N}, 17^{\circ} 02^{\prime} 52^{\prime \prime} \mathrm{W}\right)$ and one outside

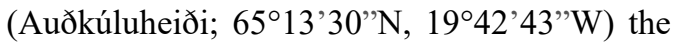
volcanic active zone (Figure 1a). Peistareykir (380 $\mathrm{m}$ ) has a mean annual temperature of 1.74 ${ }^{\circ} \mathrm{C}$ (Peistareykir weather station, IMO 2019) and mean annual precipitation of $576.9 \mathrm{~mm}$ averaged across the years 2006-2016 (Staðarholl weather station, IMO 2019). Auðkúluheiði (470 m) has a mean annual temperature of $1.02{ }^{\circ} \mathrm{C}$ and mean annual precipitation of $311.3 \mathrm{~mm}$ averaged across the years 2006-2016 (Kolka weather station, IMO 2019). Within each site we selected two common habitat types: vegetated heath (here referred to as 'dwarf heath') with $>90 \%$ low-lying vegetation cover dominated by dwarf shrubs, forbs, graminoids and other vascular plants; and sparsely vegetated habitats (here referred to as 'sparsely vegetated areas') with $<5 \%$ vegetation cover in highly exposed and eroded land dominated by forbs and graminoids (Skarphéðinsson et al. 2017).

Our experiment was designed to examine how the effects of grazing in highland summer rangelands are influenced by the application of fertilisers in different habitats within and outside the volcanic active zone. Six pairs of plots, $12 \mathrm{x}$ $12 \mathrm{~m}$ each, were selected in each habitat type, at both sites in the summer of 2015. The plot pairs were at least $100 \mathrm{~m}$ apart and the plots in each pair were separated by $4 \mathrm{~m}$. One of the plots in each pair was randomly assigned to an exclosure treatment and the other plot served as a control. In early June 2016 fences were constructed around the exclosure plots (total 12 pairs per site; Figure 1b). The fences were 1.2 $\mathrm{m}$ in height, with a mesh size of $20 \times 10 \mathrm{~cm}$ to exclude large grazing herbivores (i.e. sheep) but did not specifically exclude other herbivores present in the study area (i.e. ptarmigan and geese), although their activity within the fenced plots was limited.

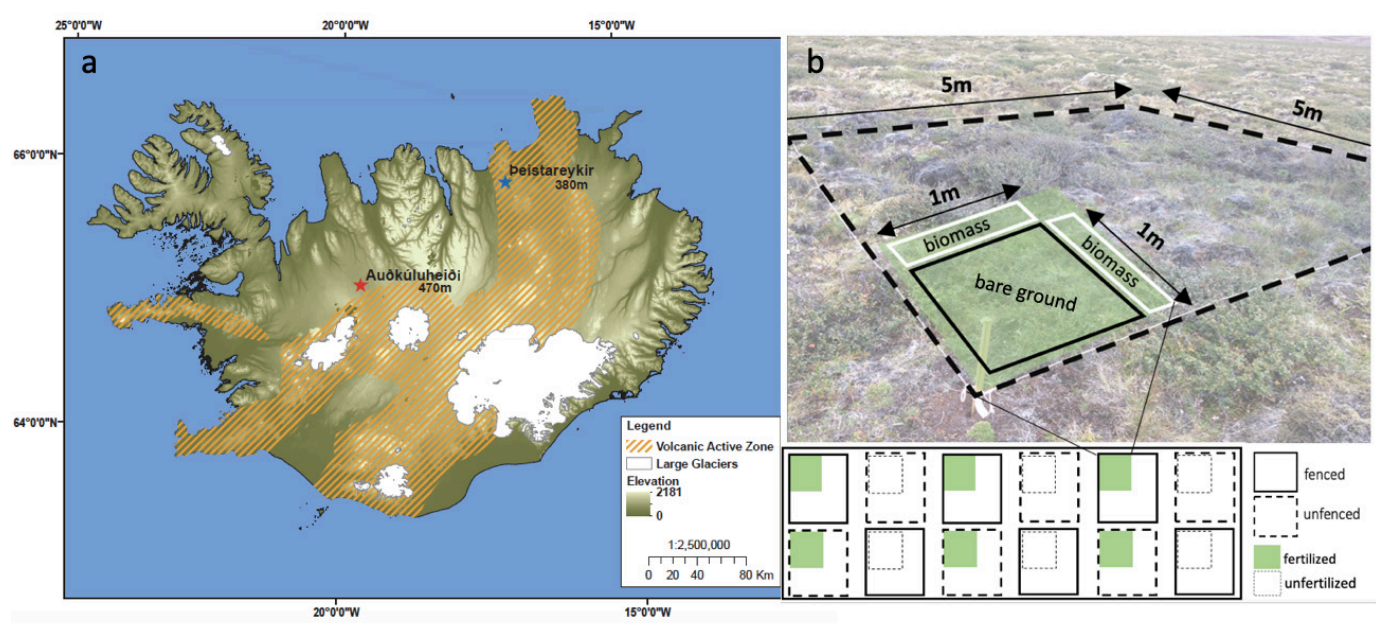

Figure 1. The experiment was conducted at two sites in Iceland (a), within (Auðkúluheiði) and outside (beistareykir) the volcanic active zone (dashed area). At each site (b), six pairs of fenced and unfenced areas were established in two habitats (dwarf-shrub heath and sparsely vegetated; diagram shows pairs of plots for one habitat). Half of these pairs received fertilisation in experimental plots $(5 \times 5 \mathrm{~m})$. Bare ground (1 x $1 \mathrm{~m})$ and aboveground biomass (two strips of $1 \times 0.1 \mathrm{~m}$ ) were measured at each plot. 
Within each fenced and control area we established 5 x $5 \mathrm{~m}$ experimental plots (Figure 1b). Each pair of plots was assigned to fertilised (NPK) or control treatments. Fertilisers containing nitrogen $\left(\mathrm{N} ; 10 \mathrm{~g} \mathrm{~m}^{-2}\right)$, phosphorus (P; $\left.10 \mathrm{~g} \mathrm{~m}^{-2}\right)$, and potassium $\left(\mathrm{K} ; 10 \mathrm{~g} \mathrm{~m}^{-2}\right)$ were applied annually in early June 2016 and 2017 following the standardized Nutrient Network protocol (Borer et al. 2014). In addition, a micronutrient mix of $\mathrm{Fe}\left(17 \mathrm{~g} \mathrm{~m}^{-2}\right), \mathrm{S}\left(12 \mathrm{~g} \mathrm{~m}^{-2}\right)$, $\mathrm{Ca}\left(6 \mathrm{~g} \mathrm{~m}^{-2}\right), \mathrm{Mg}\left(3 \mathrm{~g} \mathrm{~m}^{-2}\right), \mathrm{Mn}\left(2.5 \mathrm{~g} \mathrm{~m}^{-2}\right), \mathrm{Cu}$ $\left(1 \mathrm{~g} \mathrm{~m}^{-2}\right), \mathrm{Zn}\left(1 \mathrm{~g} \mathrm{~m}^{-2}\right), \mathrm{B}\left(0.1 \mathrm{~g} \mathrm{~m}^{-2}\right)$ and Mo $\left(0.1 \mathrm{~g} \mathrm{~m}^{-2}\right)$ was applied in the first year (Borer et al. 2014). Three pairs of plots in the sparsely vegetated area in Peistareykir (one NPK and two control pairs) were accidentally fertilised ( 5 $\mathrm{g} \mathrm{m}^{-2} \mathrm{~N}, 0.4 \mathrm{~g} \mathrm{~m}^{-2} \mathrm{P}$ ) and seeded with Festuca rubra by local farmers in the spring of 2016.

\section{Data collection}

Responses to the treatments were first monitored in early August 2017 (Figure 1b). As proxies for soil erosion and the intensity of grazing, we estimated the amount of exposed bare ground and aboveground plant biomass, respectively. Bare ground was measured in permanently marked 1 x $1 \mathrm{~m}$ subplots by visually estimating to the nearest $1 \%$ the amount of exposed bare soil or small rocks. Aboveground biomass of vascular plants was measured by clipping total annual aboveground vegetation within two $1 \times 0.1 \mathrm{~m}$ strips adjacent to the subplots; in successive years different strips were harvested. Biomass was stored in paper bags, air dried in the field and returned to the lab, where it was oven dried at $60{ }^{\circ} \mathrm{C}$ for at least $48 \mathrm{~h}$. Total biomass was weighed to the nearest $0.1 \mathrm{~g}$ and then sorted into functional groups (graminoids, forbs, and shrubs). To estimate the effects on cryptogams (lichens and mosses) visual estimates of percent cover were used, following the same procedure as for bare ground in the $1 \times 1 \mathrm{~m}$ subplots.

\section{Statistical analyses}

To describe the general conditions of the habitats and sites we focused on control plots (unfenced and non-fertilised; 3 plots per habitat per site). We calculated average values of percent cover of bare ground and total aboveground plant biomass and compared them between habitats and between sites using t-tests. In these comparisons, for the sparsely vegetated area in peistareykir, we only included the single control plot that was not accidentally fertilised.

To estimate the effects of grazing on the percent cover of bare ground, total aboveground biomass and aboveground biomass or cover of the different functional groups, we calculated the difference between unfenced and fenced plots within each pair (see McIntire and Hik 2005). A negative value of this index thus indicates that grazing reduced the corresponding measured variable, that is, the amount of bare ground, aboveground biomass, or cover. The effects of grazing were standardized (z-transformed) to allow for comparisons between effects on different variables. The overall significance of the effects of grazing on each of these variables was estimated using paired t-tests to compare unfenced and fenced plots within each pair.

To assess how different variables (application of fertilisers, habitats and sites) influence the effects of grazing on bare ground, total aboveground biomass and aboveground biomass or cover of the different functional groups, we built Linear Models (LM; 6 models). Fertiliser application, site, habitat, and all possible interactions were modelled as predictor variables. The significance of the interactions was assessed by comparing models with and without the interaction, and non-significant interactions were dropped from the models to improve our ability to interpret the main terms (Engqvist 2005). Since the accidental fertilisation affected equally both plots in each pair, and our analyses were conducted at the pair level (i.e. the effects of grazing were measured by comparing unfenced and fenced plots within a pair), our results should not be affected by the accidental fertilisation. To test this assumption, we ran the analyses with and without the accidentally fertilised pairs of plots; since results were similar (Supplementary Material), we present here the results including all plots. All analyses were conducted using $\mathrm{R}$ version 3.5.1 (R Development Core Team 2017). 


\section{RESULTS}

General conditions of the habitats and sites

The average percent cover of bare ground in control plots (unfenced and non-fertilised) differed across habitats ( $\mathrm{t}$-test; $\mathrm{t}=-8.19, \mathrm{df}=3$, $\mathrm{p}=0.03$ ) but was similar inside and outside the volcanic active zone ( $\mathrm{t}$-test; $\mathrm{t}=0.36, \mathrm{df}=5$, $\mathrm{p}=0.72$ ). In the sparsely vegetated areas, bare ground accounted for $62.6 \%$ in Auðkúluheiði, and $100.0 \%$ in the control plot in Peistareykir that was not accidentally fertilised and seeded by farmers. In the heath, percent cover of bare ground was $0.3 \%$ in Auðkúluheiði and 3.2\% in peistareykir. The average aboveground biomass of control plots was higher in heath habitats than in sparsely vegetated areas (t-test; $\mathrm{t}=4.25$, $\mathrm{df}=5, \quad \mathrm{p}<0.01$ ), but aboveground biomass showed no difference inside or outside the volcanic active zone ( $\mathrm{t}$-test; $\mathrm{t}=-2.073, \mathrm{df}=3.647$, $\mathrm{p}=0.1136$ ). Average aboveground biomass in the sparsely vegetated areas was $18.1 \mathrm{~g} \mathrm{~m}^{-2}$ in Auðkúluheiði and $0.7 \mathrm{~g} \mathrm{~m}^{-2}$ in the control plot that was not accidentally fertilised and seeded in Peistareykir, while in the heath the average aboveground biomass was 453.5 and $162.1 \mathrm{~g}$ $\mathrm{m}^{-2}$, respectively. In the heath, aboveground biomass was dominated by shrubs (85.1\%). Sparsely vegetated areas in Auðkúluheiði were not dominated by any particular functional group, but in Peistareykir graminoids (83\%) were the dominant group when considering only the plot that was not accidentally fertilised and seeded (Figure 2).

\section{Effects of grazing on bare ground}

Overall, grazing did not affect the percent cover of bare ground (paired t-test; $\mathrm{t}=-2.90, \mathrm{df}=23$, $\mathrm{p}=0.09$ ) when comparing unfenced and fenced plots within each pair. This lack of effect was consistent with and without the application of fertilisers across habitats and sites (Figure 3a; Table 1).

\section{Effects of grazing on biomass and cover}

Grazing significantly reduced total aboveground plant biomass in unfenced relative to fenced plots (paired t-test; $\mathrm{t}=-2.88, \mathrm{df}=23, \mathrm{p}=0.008$ ). However, this effect was dependent on fertiliser treatment (Figure 3b; Table 1). Grazing only reduced the amount of aboveground biomass

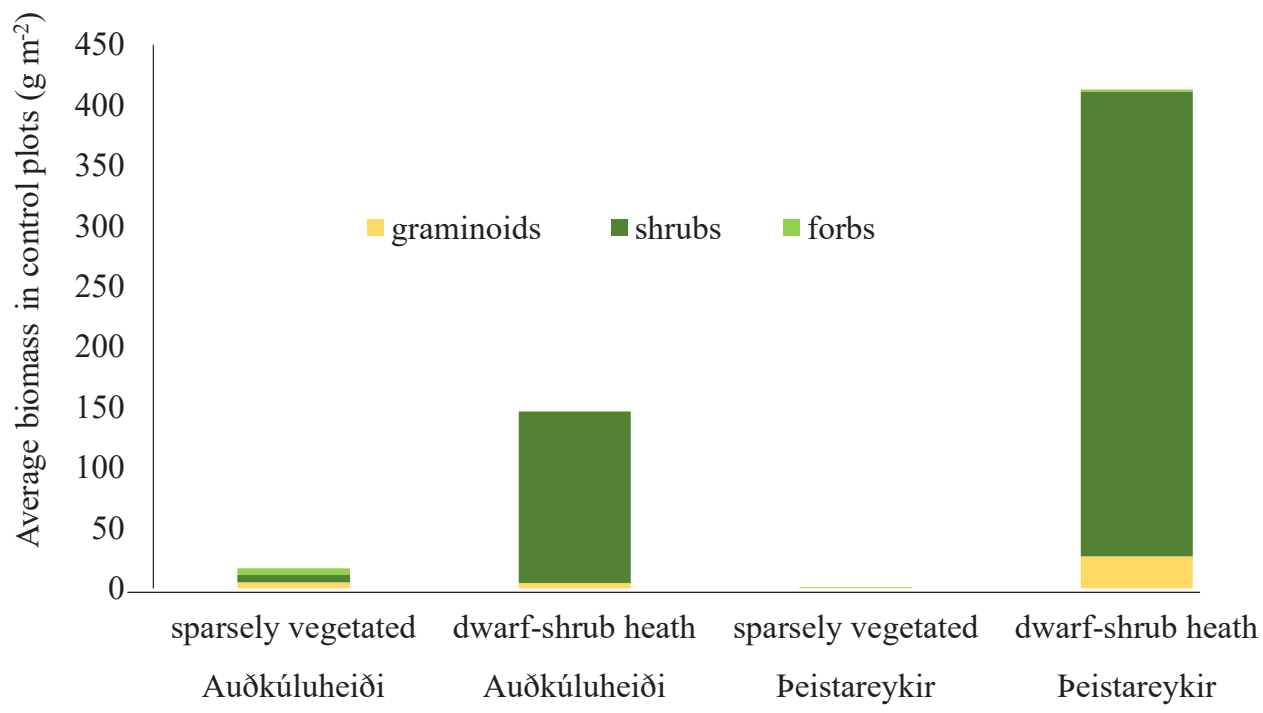

Figure 2. Distribution of average functional group biomass in control plots (unfenced, non-fertilised) across different habitats (sparsely vegetated and dwarf-shrub heath), at the two sites (Auðkúluheiði, outside the volcanic active zone; and beistareykir, inside the volcanic active zone). Note that control plots here exclude those that were accidentally fertilised by farmers. 
a

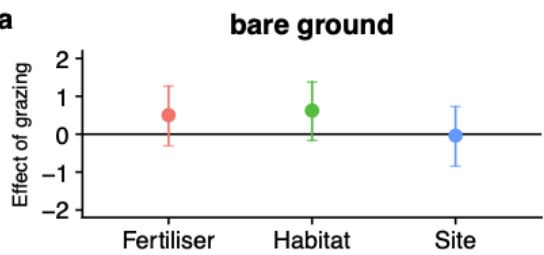

c

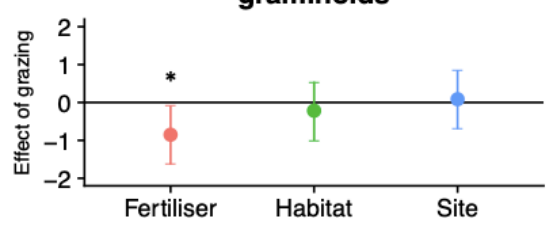

e

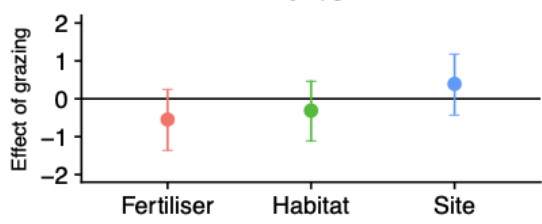

b

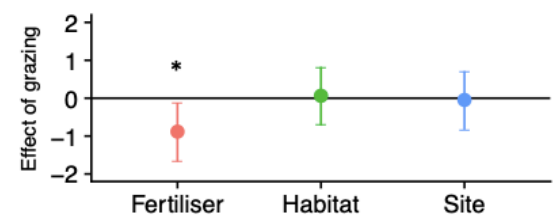

d

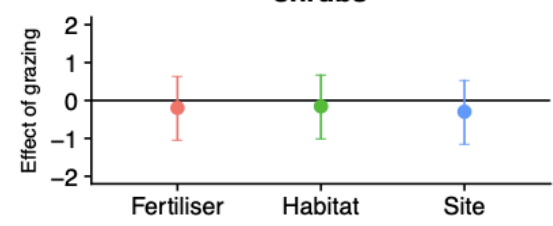

f

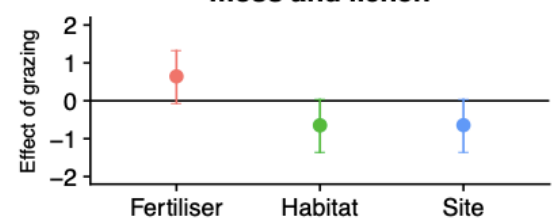

Figure 3. Effect of fertiliser application, habitat and site on the effect of grazing on a) percent cover of bare ground; b) total aboveground biomass; aboveground biomass of c) graminoids, d) shrubs, and e) forbs; and f) percent cover of moss and lichen. Model estimates are presented with $95 \%$ confidence intervals, and baseline levels refer to non-fertilised, heath plots outside the volcanic active zone. Therefore, negative (or positive) values of the effect of grazing indicate that grazing reduced (or increased) the corresponding measured variable in fertilised relative to non-fertilised plots, in heath plots relative to sparsely vegetated areas, and inside relative to outside the volcanic active zone. A significant effect of grazing $(\mathrm{p}<0.05)$ is marked with an asterisk.

Table 1. Effect of fertiliser application, habitat and site, and all possible interactions on the effect of grazing on total biomass, graminoids, forbs, shrubs, moss and lichen, and bare ground. The significance of the interactions was assessed by comparing models with and without the interaction. An asterisk indicates significant effects $(\mathrm{p}<0.05)$.

\begin{tabular}{|c|c|c|c|c|c|c|}
\hline Interactions & Bare Ground & Total Biomass & Graminoids & Shrubs & Forbs & $\begin{array}{r}\text { Moss and } \\
\text { Lichen }\end{array}$ \\
\hline Fertiliser:Habitat:Site & $\begin{array}{r}F=0.13 \\
p=0.719\end{array}$ & $\begin{array}{r}F=1.85 \\
p=0.191\end{array}$ & $\begin{array}{r}F=0.88 \\
p=0.359\end{array}$ & $\begin{array}{r}F=0.62 \\
p=0.439\end{array}$ & $\begin{array}{r}F=2.51 \\
p=0.132\end{array}$ & $\begin{array}{r}\mathrm{F}=3.05 \\
\mathrm{p}=0.099\end{array}$ \\
\hline Site:Habitat & $\begin{array}{r}\mathrm{F}=0.02 \\
\mathrm{p}=0.872\end{array}$ & $\begin{array}{r}\mathrm{F}=2.02 \\
\mathrm{p}=0.172\end{array}$ & $\begin{array}{r}\mathrm{F}=0.20 \\
\mathrm{p}=0.654\end{array}$ & $\begin{array}{r}F=0.11 \\
p=0.741\end{array}$ & $\begin{array}{r}\mathrm{F}=1.53 \\
\mathrm{p}=0.230\end{array}$ & $\begin{array}{r}\mathrm{F}=0.01 \\
\mathrm{p}=0.920\end{array}$ \\
\hline Fertiliser:Site & $\begin{array}{r}\mathrm{F}=0.83 \\
\mathrm{p}=0.372\end{array}$ & $\begin{array}{r}F=1.09 \\
p=0.310\end{array}$ & $\begin{array}{r}F=0.77 \\
p=0.391\end{array}$ & $\begin{array}{r}\mathrm{F}=0.03 \\
\mathrm{p}=0.864\end{array}$ & $\begin{array}{r}\mathrm{F}=0.82 \\
\mathrm{p}=0.375\end{array}$ & $\begin{array}{r}\mathrm{F}=0.01 \\
\mathrm{p}=0.933\end{array}$ \\
\hline Habitat:Fertiliser & $\begin{array}{r}F=0.52 \\
p=0.479\end{array}$ & $\begin{array}{r}\mathrm{F}=0.01 \\
\mathrm{p}=0.981\end{array}$ & $\begin{array}{r}\mathrm{F}=0.01 \\
\mathrm{p}=0.991\end{array}$ & $\begin{array}{r}\mathrm{F}=0.10 \\
\mathrm{p}=0.748\end{array}$ & $\begin{array}{r}\mathrm{F}=2.15 \\
\mathrm{p}=0.158\end{array}$ & $\begin{array}{r}\mathrm{F}=0.00 \\
\mathrm{p}=0.932\end{array}$ \\
\hline Fertiliser & $\begin{array}{r}\mathrm{F}=1.58 \\
\mathrm{p}=0.222\end{array}$ & $\begin{array}{r}\mathrm{F}=5.13 \\
\mathrm{p}=0.034^{*}\end{array}$ & $\begin{array}{r}\mathrm{F}=4.73 \\
\mathrm{p}=0.041^{*}\end{array}$ & $\begin{array}{r}\mathrm{F}=0.20 \\
\mathrm{p}=0.652\end{array}$ & $\begin{array}{r}\mathrm{F}=1.82 \\
\mathrm{p}=0.191\end{array}$ & $\begin{array}{r}\mathrm{F}=3.20 \\
\mathrm{p}=0.088\end{array}$ \\
\hline Habitat & $\begin{array}{r}\mathrm{F}=2.42 \\
\mathrm{p}=0.135\end{array}$ & $\begin{array}{r}\mathrm{F}=0.01 \\
\mathrm{p}=0.904\end{array}$ & $\begin{array}{r}\mathrm{F}=0.30 \\
\mathrm{p}=0.585\end{array}$ & $\begin{array}{r}\mathrm{F}=0.12 \\
\mathrm{p}=0.724\end{array}$ & $\begin{array}{r}\mathrm{F}=0.58 \\
\mathrm{p}=0.452\end{array}$ & $\begin{array}{r}\mathrm{F}=3.20 \\
\mathrm{p}=0.088\end{array}$ \\
\hline Site & $\begin{array}{r}\mathrm{F}=0.01 \\
\mathrm{p}=0.924\end{array}$ & $\begin{array}{r}\mathrm{F}=0.02 \\
\mathrm{p}=0.872\end{array}$ & $\begin{array}{r}\mathrm{F}=0.04 \\
\mathrm{p}=0.827\end{array}$ & $\begin{array}{r}\mathrm{F}=0.47 \\
\mathrm{p}=0.497\end{array}$ & $\begin{array}{r}\mathrm{F}=0.94 \\
\mathrm{p}=0.343\end{array}$ & $\begin{array}{r}\mathrm{F}=3.24 \\
\mathrm{p}=0.086\end{array}$ \\
\hline
\end{tabular}




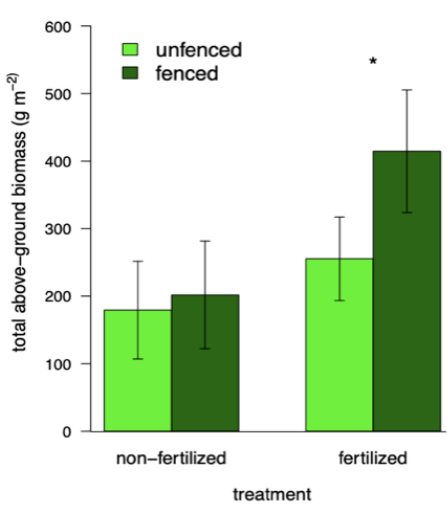

Figure 4. Total aboveground biomass $\left(\mathrm{g} \mathrm{m}^{-2}\right)$ in plots with or without grazing (i.e. unfenced or fenced, respectively), with and without fertiliser application. The asterisk indicates a significant difference between unfenced and fenced fertilised plots $(\mathrm{p}<0.05)$.

in fertilised plots (paired t-test; $\mathrm{t}=-2.96, \mathrm{df}=11$, $\mathrm{p}=0.01$ ) but not in non-fertilised plots (paired t-test; $\mathrm{t}=-1.08, \mathrm{df}=11, \mathrm{p}=0.30$; Figure 4).

Fertiliser application also influenced the effect of grazing on the aboveground biomass of graminoids (Figure 3c; Table 1). Similar to total biomass, the aboveground biomass of graminoids was reduced by grazing in fertilised plots (paired t-test; $\mathrm{t}=-3.00, \mathrm{df}=11, \mathrm{p}=0.01$ ) but not in non-fertilised plots (paired t-test; $\mathrm{t}=$ $1.02, \mathrm{df}=11, \mathrm{p}=0.32$ ). Grazing did not affect the aboveground biomass of other functional groups (shrubs: paired t-test; $\mathrm{t}=0.10, \mathrm{df}=23, \mathrm{p}=0.92$; forbs: paired t-test; $\mathrm{t}=-1.53, \mathrm{df}=23, \mathrm{p}=0.13$ ) or the cover of cryptograms (paired t-test; $\mathrm{t}=0.03, \mathrm{df}=23, \mathrm{p}=0.97$ ). These results were consistent with and without the application of fertilisers and across habitats and sites (Figure 3d-f). Although not significant, grazing tended to increase the cover of moss and lichen with fertiliser application and reduce the cover of moss and lichen in sparsely vegetated areas and within the beistareykir site (Figure 3f; Table 1).

\section{DISCUSSION}

Overall, we found that sheep grazing reduced the total aboveground plant biomass in summer rangelands of Iceland in both sparsely and well vegetated habitats and inside and outside the volcanic active zone, but only when these areas were treated with fertilisers. These effects of grazing, however, did not translate into changes in the amount of bare ground. Our interpretation of this pattern is that grazing had a neutral effect on bare ground, but the intensity of grazing, as approximated by the amount of plant biomass removed, was high in fertilised plots and low (or almost non-existent) in non-fertilised plots.

Fertilisers can increase the amount and quality of vegetation, making fertilised areas more attractive to herbivores (Ball et al. 2000, Grellmann 2002). Herbivore attraction could explain the observed lack of grazing effect in non-fertilised plots, if sheep are concentrating their foraging on fertilised plots, reducing their use of non-fertilised plots. Alternatively, it could indicate that current grazing pressure in these rangelands is relatively low. However, the absence of a strong grazing effect in our experiment may also suggest that two years is not long enough to detect the effect of excluding sheep from degraded ecosystems (Jónsdóttir et al. 2005). Sheep numbers in Iceland reached a historical maximum in 1977 (Arnalds \& Barkarson 2003), but with the introduction of a livestock quota in 1985, stocking rates were reduced by half and have remained relatively stable. Nevertheless, sheep numbers are still considered to be high relative to historical abundances (Marteinsdóttir et al. 2017).

The effects of grazing on aboveground biomass were dominated by graminoids, with grazing reducing graminoid biomass in fertilised plots. These effects are likely due to the ability of graminoids to respond quickly to the flux of soil nutrients provided by fertiliser applications (Greipsson and El-Mayas 1999, Shaver \& Chapin 1986). In the highlands, the grasses that respond fastest to fertilisers, such as Festuca, Agrostis and Poa species (Arnalds et al. 1987), are also the species that sheep selectively graze when available (Austrheim et al. 2008). In turn, graminoids are often resilient to losses of biomass by grazing due to adaptations, such as sequential leaf production and basal leaf meristems (Archer \& Tieszen 1983, Kotanen \& Jefferies 1987, Jónsdóttir 1991). By promoting 
the abundance of graminoids, even if more intensively grazed, fertilisers could help maintain a vegetative layer that protects the soil from erosion and the formation of bare ground patches, even with the associated increase in trampling.

Contrary to our predictions and to the general trends found in the ecological literature in Iceland (Marteinsdóttir et al. 2017), we found no effect of grazing on the extent of bare ground. Interestingly, this lack of effect was consistent both inside and outside the volcanic active zone. This finding contradicts the hypothesis that grazing, by increasing the amount of bare ground, will be more damaging in the volcanic active zone (Arnalds \& Barkarson 2003). However, it is important to emphasize that our experiment only assessed the short-term effects of grazing exclusion, and we cannot discard that in the long-term, increased use of certain areas by sheep, for example in or around the fertilised plots, may lead to greater amounts of exposed bare ground. The effects of reducing grazing pressure (i.e. grazing exclusion) on bare ground will depend on the ability of local species to recolonize an area, a process that can take a long time (Jónsdóttir et al. 2005). This is especially true in tundra systems where many dominant species have slow growth patterns and the colonization of barren soils is limited by harsh environmental conditions (Chapin et al. 1986, Elmarsdóttir et al. 2003, Marteinsdóttir et al. 2010, Eskelinen et al. 2017).

The use of fertilisers has been suggested as a tool to better distribute herbivore densities and ameliorate forest damage by herbivores (Ball et al. 2000). Historically, fertiliser application was used to restore eroded areas in the highlands of Iceland at a large-scale through aerial application, until this practice was deemed too costly and slow to instigate succession and was discontinued (Greipsson \& El-Mayas 1999). While our study was not specifically designed to test for the effects of grazing on areas near fertiliser application, the higher grazing intensity on the fertilised plots and the lack of effect of grazing in our unfertilised plots suggests that the use of fertilisers in some patches may release other nearby areas from grazing. Similar to earlier restoration studies, areas that used fertilisers reported that non-fertilised areas nearby were less grazed (Arnalds et al. 1987). It is worth noting that the rates of fertiliser application typically used for land restoration in Iceland (2.5-5 $\mathrm{N} \mathrm{g} \mathrm{m}^{-2}$ Aradóttir et al. 2000) are half of those used in our study and the elements were also applied at different ratios (Borer et al. 2014). These differences may influence the effectiveness of the fertiliser application in the presence or absence of grazing.

High grazing intensity also leads to high trampling intensity. Many studies have found trampling to have a negative effect on vegetation, especially of moss and lichen cover (Jónsdóttir 1991, Bayfield et al. 1981, Olofsson 2006, Sørensen et al. 2009, Olofsson et al. 2010), though no fertiliser was applied in these studies. Our results did not show any signs of increased cover of bare ground as a consequence of increased grazing intensity, which could be an indication that fertiliser application may prevent the negative impacts of increased trampling. A better understanding of the longer-term effects of fertilisers, as well as other consequences of herbivores on vegetation will be necessary before widely adopting fertiliser applications into grazing management practices.

\section{CONCLUSIONS}

We found that short-term grazing exclusion has little effect on the amount of bare ground in two habitats with contrasting vegetation cover and in areas inside and outside the volcanic active zone. Grazing reduced aboveground plant biomass only in fertilised plots, whereas biomass in non-fertilised plots was not affected. This could be the result of preferential grazing, where sheep selectively graze fertilised plots. Although we did not find specific habitats or sites to be more sensitive to sheep grazing, longer term monitoring would offer a more realistic representation. We found that the effect of grazing was higher on fertilised plots across varying environmental conditions in the highlands. This could imply that fertiliser application increased the attractiveness of the 
patch for grazing, which could lead to reduced grazing pressure in nearby areas. With a better understanding of the long-term effects of increased trampling on bare ground, fertilisers could possibly be used as a method of regulating sheep distribution and minimizing grazing pressure on more sensitive land.

\section{ACKNOWLEDGEMENTS}

We thank L. Pitti, A.B. Ólafsdóttir, K. Valsdóttir and H.V. Friðriksdóttir for help with sorting plant biomass and J. Varney for mapping the sites. Funding for this study was provided by Orkurannsóknasjóður Landsvirkjunar (NÝR09-2017, NÝR-14-2018, NÝR-12-2019) and the Natural Sciences and Engineering Research Council (Canada). This study is a contribution to the Nutrient Network (http://nutnet.org).

\section{REFERENCES}

Aradóttir ÁL, Svavarsdóttir K, Jónsson TH \& Gudbergsson G 2000. Carbon accumulation in vegetation and soils by reclamation of degraded areas. Icelandic Agricultural Sciences 13, 99-113.

Archer S \& Tieszen LL 1983. Effects of simulated grazing on foliage and root production and biomass allocation in an arctic tundra sedge (Eriophorum vaginatum). Oecologia 58, 92-102.

https://doi.org/10.1007/BF00384547.

Arnalds Ó 2015. The soils of Iceland. World Soils Book Series. Springer, Dordrecht, the Netherlands. $180 \mathrm{p}$.

Arnalds Ó 2008. The Soils of Iceland. Jokull 58, 409-421.

https://doi.org/10.1097/00010694-196104000-00017.

Arnalds Ó \& Barkarson BH 2003. Soil erosion and land use policy in Iceland in relation to sheep grazing and government subsidies. Environmental Science \& Policy 6, 105-113.

https://doi.org/10.1016/S1462-9011(02)00115-6.

Arnalds Ó, Aradóttir ÁL \& Thorsteinsson I 1987. The nature and restoration of denuded reas in Iceland. Arctic and Alpine Research 19, 518-525. https://doi.org/10.2307/1551419.

Austrheim G, Asheim LG, Bjarnason G, Fosaa AM, Holand $\varnothing$, Hoegh $K$, Mosrtensen LE, Mysterud A, Olsen E, Skonhoft A, Steinheim G, Thórhallsdóttir AG, Jónsdóttir IS \& Magnússon B 2008. Sheep grazing in the North-Atlantic region: A long term perspective on management, resource economy and ecology. Vitenskapsmuseet, Rapport Zoology Series 3, 86 p.

Ball JP, Danell K \& Sunesson P 2000. Response of a herbivore community to increased food quality and quantity: an experiment with nitrogen fertiliser in a boreal forest. Journal of Applied Ecology 37, 247-255.

https://doi.org/10.1046/j.1365-2664.2000.00487.x.

Bayfield NG, Urquhart UH \& Cooper SM 1981. Susceptibility of four species of Cladonia to disturbance by trampling in the Cairngorm Mountains, Scotland. Journal of Applied Ecology 18, 303-310.

https://doi.org/10.2307/2402497.

Borer ET, Harpole SW, Adler PB, Lind EM, Orrock JL, Seabloom EW \& Smith MD 2014. Finding generality in ecology: A model for globally distributed experiments. Methods in Ecology and Evolution 5, 65-73.

https://doi.org/10.1111/2041-210X.12125.

Chapin FS, Vitousek PM \& Cleve KV 1986. The nature of nutrient limitation in plant communities. The American Naturalist 127, 48-58.

https://doi.org/10.1086/28446.

Chapin FS 1980. The mineral nutrition of wild plants. Annual Review of Ecology and Systematics 11, 233-260.

https://doi.org/10.1146/annurev.es.11.110180.001313.

Elmarsdóttir Á, Aradóttir ÁL \& Trlica MJ 2003. Microsite availability and establishment of native species on degraded and reclaimed sites. Journal of Applied Ecology 40, 815-823.

https://doi.org/10.1046/j.1365-2664.2003.00848.x.

Engqvist L 2005. The mistreatment of covariate interaction terms in linear model analyses of behavioural and evolutionary ecology studies. Animal Behaviour 70, 967-971. https://doi.org/10.1016/j.anbehav.2005.01.016.

Eskelinen A 2008. Herbivore and neighbour effects on tundra plants depend on species identity, nutrient availability and local environmental conditions. Journal of Ecology 96, 155-165. https://doi.org/10.1111/j.1365-2745.2007.01322.x.

Eskelinen A, Kaarlejärvi E \& Olofsson J 2017. Herbivory and nutrient limitation protect warming tundra from lowland species' invasion and diversity loss. Global Change Biology 23, 245-255. https://doi.org/10.1111/gcb.13397. 
Forbes BC, Ebersole JJ \& Strandberg B 2001. Anthropogenic disturbance and patch dynamics in circumpolar Arctic ecosystems. Conservation Biology 15, 954-969.

https://doi.org/10.1046/j.1523-1739.2001.015004954.x.

Gough L, Bettez ND, Slavik KA, Bowden WB, Giblin AE, Kling GW, Laundre JA \& Shaver GA 2016. Effects of long-term nutrient additions on Arctic tundra, stream, and lake ecosystems: Beyond NPP. Oecologia 182, 653-665. https://doi.org/10.1007/s00442-016-3716-0.

Gough L, Moore JC, Shaver GR, Simpson RT \& Johnson DR 2012. Above and belowground responses of Arctic tundra ecosystems to altered soil nutrients and mammalian herbivory. Ecology 93, 1683-1694.

https://doi.org/10.1890/11-1631.1.

Gough L, Ramsey E \& Johnson DR 2007. Plantherbivore interactions in Alaskan Arctic tundra change with soil nutrient availability. Oikos 116, 407-418.

https://doi.org/10.1111/j.0030-1299.2007.15449.x.

Greipsson S \& El-Mayas H 1999. Large-scale reclamation of barren lands in Iceland by aerial seeding. Land Degradation and Development 10, 185-193.

ht tps://doi org/ $10.1002 /$ ( S I C I) 1099 145X(199905/06)10:3<185::AID-LDR327>3.0.CO;2-R

Grellmann D 2002. Plant responses to fertilisation and exclusion of grazers on an Arctic tundra heath. Oikos 98, 190-204.

https://doi.org/10.1034/j.1600-0706.2002.980202.x.

Grétarsdóttir J, Aradóttir ÁL, Vandvik V, Heegaard E \& Birks HJB 2004. Long-term effects of reclamation treatments on plant succession in Iceland. Restoration Ecology 12, 268-278. https://doi.org/10.1111/j.1061-2971.2004.00371.x.

Gudmundsson Ó \& Thórhallsdóttir AG 1999. Extensive sheep grazing in the North. In: Grazing and pasture management in the Nordic countries. Proceedings and NJF- seminar no. 305. As, Norway, pp. 52-60.

Gunnlaugsdóttir E 1985. Composition and dynamical status of heathland communities in Iceland in relation to recovery measures. Acta Phytogeographica Suecica 75, 1-84.

Harpole WS, Sullivan LL, Lind EM, et al 2017. Out of the shadows: multiple nutrient limitations drive relationships among biomass, light and plant diversity. Functional Ecology 31, 1839-1846.

https://doi.org/10.1111/1365-2435.12967

IMO [Icelandic Meteorological Office] 2019. Icelandic Meteorological Data. Accessed 15.07.2019 at https://www.vedur.is/

Jónsdóttir IS 1991. Effects of grazing on tiller size and population dynamics in a clonal sedge (Carex bigelowii). Oikos 62, 177-88.

Jónsdóttir IS, Magnússon B, Gudmundsson J, Elmarsdóttir A \& Hjartarson H 2005. Variable sensitivity of plant communities in Iceland to experimental warming. Global Change Biology 11, 553-563.

https://doi.org/10.1111/j.1365-2486.2005.00928.x

Kotanen P \& Jefferies RL 1987. The leaf and shoot demography of grazed and ungrazed plants of Carex subspathacea. Journal of Ecology 75, 961975.

Marteinsdóttir B, Barrio IC \& Jónsdóttir IS 2017. Assessing the ecological impacts of extensive sheep grazing in Iceland. Icelandic Agricultural Sciences 30, 55-72.

https://doi.org/10.16886/ias.2017.07.

Marteinsdóttir B, Svavarsdóttir $\quad K \quad$ \& Thórhallsdóttir TE 2010. Development of vegetation patterns in early primary succession. Journal of Vegetation Science 21, 531-540. https://doi.org/10.1111/j.1654-1103.2009.01161.x.

McIntire EJB \& Hik DS 2005. Influences of chronic and current season grazing by collared pikas on above-ground biomass and species richness in subarctic alpine meadows. Oecologia 145, 288297.

https://doi.org/10.1007/s00442-005-0127-z.

Militino AF 2010. Mixed effects models and extensions in ecology with R. Journal of the Royal Statistical Society: Series A (Statistics in Society) 173, 938-939. https://doi.org/10.1111/j.1467-985x.2010.00663_9.x.

Mobæk R, Mysterud A, Holand Ø \& Austrheim G 2012. Age class, density and temporal effects on diet composition of sheep in an alpine ecosystem. Basic and Applied Ecology 13, 466-474. https://doi.org/10.1016/j.baae.2012.06.009.

Morrissette-Boileau C, Boudreau S, Tremblay JP \& Côté SD 2018. Simulated caribou browsing limits the effect of nutrient addition on the growth 
of Betula glandulosa, an expanding shrub species in Eastern Canada. Journal of Ecology 106, 12561265.

https://doi.org/10.1111/1365-2745.12899.

Olofsson J 2006. Short- and long-term effects of changes in reindeer grazing pressure on tundra heath vegetation. Journal of Ecology 94, 431-440. https://doi.org/10.1111/j.1365-2745.2006.01100.x.

Olofsson J, Moen J \& Östlund L 2010. Effects of reindeer on boreal forest floor vegetation: does grazing cause vegetation state transitions? Basic and Applied Ecology 11, 550-557. https://doi.org/10.1016/j.baae.2010.03.004.

Óskarsson H, Sigurgeirsson A \& RaulundRasmussen K 2006. Survival, growth, and nutrition of tree seedlings fertilised at planting on andisol soils in Iceland: six-year results. Forest Ecology and Management 229, 88-97.

https://doi.org/10.1016/j.foreco.2006.03.018.

R Development Core Team 2017. R: A language and environment for statistical computing. $\mathrm{R}$ Foundation for Statistical Computing, Vienna, Austria. URL: http://www.r-project.org

Ross LC, Austrheim G, Asheim JL, Bjarnason G, Feilberg J, Fosaa AM, Hester AJ, Holand Ø, Jónsdóttir IS, Mortensen LE, Mysterud A, Olsen E, Skonhoft A, Speed JDM, Steinheim G, Thompson DBA, Thórhallsdóttir AG 2016. Sheep grazing in the North Atlantic region: a longterm perspective on environmental sustainability. Ambio 45, 551-566.

https://doi.org/10.1007/s13280-016-0771-z.

Shaver GR \& Chapin FS 1986. Effect of fertiliser on production and biomass of tussock tundra, Alaska, U.S.A. Arctic and Alpine Research 18, 261-268. https://doi.org/10.2307/1550883.

Shaver GR \& Chapin FS 1995. Long-term responses to factorial, NPK fertiliser treatment by Alaskan wet and moist tundra sedge species. Oikos 18, 259-275.

Skarphéðinsson KH, Katrínardóttir B, Guðmundsson GA \& Auhage SNV 2016. Mikilvæg fuglasvæði á Íslandi [Important bird habitats in Iceland]. Fjölrit Náttúrufrceðistofnunar 55, 295 p. [in Icelandic]

\section{Sørensen LI, Mikola J, Kytöviita MM \& Olofsson}

J 2009. Trampling and spatial heterogeneity explain decomposer abundances in a Sub-Arctic grassland subjected to simulated reindeer grazing. Ecosystems 12, 830-842. https://doi.org/10.1007/s10021-009-9260-6.

Stark S, Strömmer R \& Tuomi J 2002. Reindeer grazing and soil microbial processes in two suboceanic and two subcontinental tundra heaths. Oikos 97, 69-78. https://doi.org/10.1034/j.1600-0706.2002.970107.x.

Thórhallsdóttir TE 1997. Tundra ecosystems of Iceland. In: Wielgolaski FE (ed.) Ecosystems of the World: Polar and Alpine Tundra. Elsevier, Amsterdam, pp. 152-163.

Manuscript received 26 August 2019 Accepted 27 November 2019 